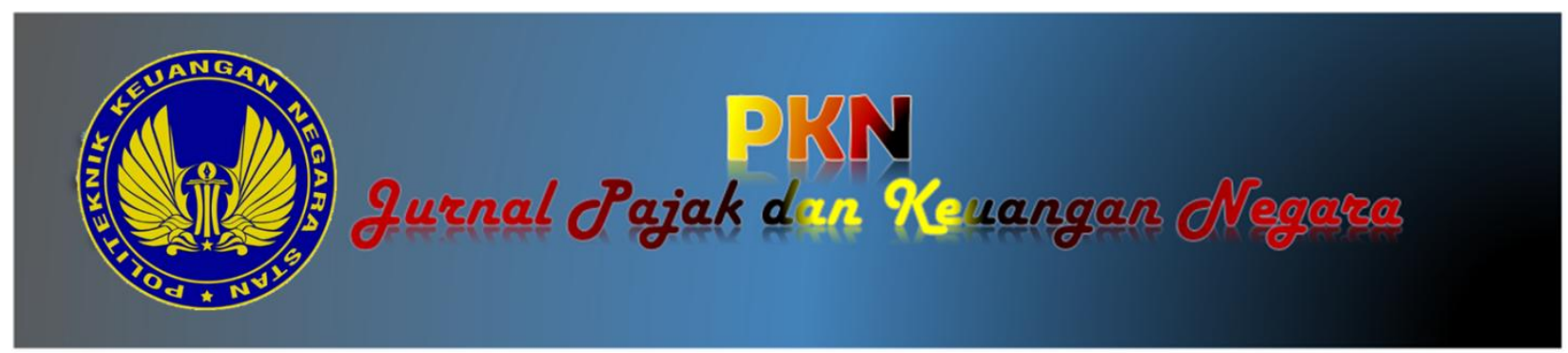

\title{
PENGARUH DANA PERIMBANGAN DAN BELANJA MODAL TERHADAP KEMANDIRIAN DAERAH
}

\author{
Nina Andriana \\ Politeknik Keuangan Negara STAN \\ Alamat Korespondensi: nina.andriana@pknstan.ac.id
}

\section{INFORMASI ARTIKEL}

Diterima Pertama

[dd mmyyyy]

Dinyatakan Diterima

[dd mm yyyy]

KATA KUNCI:

Dana Alokasi Umum, Dana Alokasi Khusus, Dana Bagi Hasil, Belanja Modal, dan Kemandirian Daerah. (General Allocation Fund, Spesial Allocation Fund, Revenue Sharing Fund, Capital Expenditure, and Regional Independence).

KLASIFIKASI JEL:

[Untuk klasifikasi keywords menggunakan standard JEL codes yang dapat diakses pada http://www.aeaweb.org/jel/guide/jel.php].

\begin{abstract}
The purpose of this study is to investigate the Fund Budget and Capital Expenditure on Regional Independence. The sample in this study was taken by purposive sampling from 150 districts/cities within four years-period. The study uses panel data. Data is taken from the official website of the Directorate General of Fiscal Balance. The author uses multiple regression with the fixed effect method that is processed with STATA. The results showed that: (1) the General Allocation Fund does not significantly influence regional independence. (2) Special Allocation Fund has a significant influence on regional independence. (3) Revenue Sharing Fund does not significantly influence on regional independence. (4) Capital expenditure has a positive coefficient but does not significantly affect regional independence. (5) General Allocation Fund, Special Allocation Fund, Revenue Sharing Fund and Capital Expenditure simultaneously have a significant influence on regional independence.
\end{abstract}

\section{ABSTRAK}

Penelitian ini bertujuan untuk menginvestigasi pengaruh dana perimbangan dan Belanja Modal terhadap Kemandirian Daerah. Sampel dalam penelitian ini diperoleh secara purposive sampling dari 150 kabupaten/kota dalam jangka waktu 4 tahun. Penelitian menggunakan data panel. Data diambil dari situs resmi Direktorat Jenderal Perimbangan Keuangan. Penulis menggunakan regresi berganda dengan fixed effect method yang diolah dengan STATA. Hasil penelitian menunjukkan bahwa: (1) Dana Alokasi Umum tidak signifikan berpengaruh terhadap kemandirian daerah. (2) Dana Alokasi Khusus mempunyai pengaruh signifikan terhadap kemandirian daerah. (3) Dana Bagi Hasil tidak berpengaruh secara signifikan terhadap kemandirian daerah. (4) Belanja Modal mempunyai koefisien positif namun tidak signifikan mempengaruhi kemandirian daerah. (5) Dana Alokasi Umum, Dana Alokasi Khusus, Dana Bagi Hasil, dan Belanja Modal secara simultan mempunyai pengaruh yang signifikan terhadap kemandirian daerah. 


\section{PENDAHULUAN}

\subsection{Latar Belakang}

Undang-undang Nomor 22 tahun 1999 tentang Pemerintahan Daerah merupakan cikal bakal adanya otonomi daerah di Indonesia. Dalam Undang-undang tersebut kewenangan untuk mengatur dan mengurus kepentingan masyarakat setempat menurut prakarsa sendiri, berdasarkan aspirasi masyarakat sesuai dengan peraturan perundang-undangan, yang diakukan oleh daerah otonom, diterjemahkan sebagai definisi dari otonomi daerah. Oates (1999) menyatakan bahwa alokasi sumber daya yang lebih efisien dan ekonomis akan tercipta dari pengaplikasian desentralisasi fiskal karena pemerintah daerah lebih memahami apa saja kebutuhan daerahnya sendiri.

Tujuan utama otonomi daerah secara umum adalah memberikan kewenangan kepada daerah untuk mengelola keuangannya secara mandiri agar pengelolaan keuangan sesuai dengan kebutuhan yang diperlukan oleh masing-masing daerah sehingga pengelolaan keuangan menjadi lebih efektif dan tepat sasaran. Daerah memahami kebutuhannya masingmasing dan dapat mengalokasikan sumber daya yang dimiliki sesuai dengan kebutuhan. Hal ini sangat berbeda dengan sistem sentralisasi fiskal di mana pemerintah pusat yang mengendalikan keuangan daerah.

Sebagai konsekuensi atas otonomi daerah maka perlu diatur mengenai hubungan antara pemerintah pusat dengan pemerintah daerah. Undang-undang Nomor 33 Tahun 2004 tentang Perimbangan Keuangan Pusat dan Daerah menyatakan bahwa dengan adanya desentralisasi fiskal pemerintah daerah berhak untuk mengatur susunan pendapatan dan pengeluaran yang dibutuhkan dalam memberikan pelayanan publik kepada masyarakat dalam bentuk Anggaran Pendapatan dan Belanja Daerah (APBD). Agar Pemerintah Daerah dapat memberikan pelayanan publik secara lebih efektif dan efisien maka harus didukung oleh sumber-sumber keuangan yang mencukupi, baik yang bersumber dari Pendapatan Asli Daerah (PAD), Dana Perimbangan, pinjaman, maupun bantuan dari Pemerintah Pusat atau Daerah Lainnya (Sidik, 2002).

Dalam rangka pelaksanaan otonomi daerah, pemerintah pusat memberikan dana perimbangan kepada daerah. Pemberian dana perimbangan ini dimaksudkan untuk mengurangi kesenjangan fiskal antara pemerintah pusat dan pemerintah daerah dan antar pemerintah daerah (Pasal 3 ayat (2) UU Nomor 33 Tahun 2004). Kemampuan keuangan daerah yang beragam menuntut pemerintah pusat untuk dapat menyelaraskan sehingga tidak terjadi ketimpangan antar daerah, untuk itu pemerintah pusat memberikan dana perimbangan kepada pemerintah daerah.

Selain sebagai alat penyeimbangan keuangan antar pemerintahan, dana perimbangan juga dimaksudkan sebagai stimulus pembangunan di daerah sehingga secara bertahap daerah mampu meningkatkan pendapatan yang berasal dari daerah tersebut yang berupa Pendapatan Asli Daerah. Pemberian dana perimbangan oleh pemerintah pusat seyogyanya dapat dijadikan pendongkrak perekonomian di daerah tersebut yang pada akhirnya akan meningkatkan pendapatan asli daerah baik berupa pajak, retribusi, hasil pengelolaan kekayaan dareah yang dipisahkan, maupun lain-lain pendapatan daerah yang sah.

Dana perimbangan yang digelontorkan oleh pusat kepada daerah berbentuk antara lain: Dana Alokasi Umum (DAU), Dana Alokasi Khusus (DAK), dan Dana Bagi Hasil (DBH). Ketiga jenis dana perimbangan ini mempunyai karakteristik yang berbeda-beda. DAU diberikan oleh pemerintah pusat ke pemerintah daerah dalam bentuk gelondongan yang dapat dibelanjakan oleh pemerintah daerah tanpa batasan penggunaan/peruntukkan untuk memberikan pelayanan kepada masyarakat. Sedangkan DAK adalah dana yang diterima oleh pemerintah daerah dari pemerintah pusat yang peruntukkannya telah ditetapkan oleh pemerintah pusat. Daerah tidak memiliki kewenangan untuk menentukan kegunaannya. Peruntukan DAK telah ditetapkan oleh pemerintah pusat, meskipun DAK menjadi pendapatan daerah namun penggunaan/belanjanya telah ditetapkan. Peruntukkan DAK ini dapat berupa belanja fisik (DAK Fisik) maupun non-fisik (DAK Non-fisik). Selain DAU dan DAK pemerintah juga memberikan DBH kepada daerah. DBH pada dasarnya adalah dana yang diberikan oleh pemerintah pusat kepada daerah dengan proporsi tertentu sebagai imbal jasa atas penerimaan pendapatan pemerintah pusat yang bersal dari daerah. DBH terdiri dari Bagi Hasil Pajak (DBH-Pajak) dan Bagi Hasil Sumber Daya Alam (DBH-SDA).

Pemberian dana perimbangan ke pemerintah daerah diharapkan dapat mewujudkan adanya otonomi daerah sesuai dengan perundangan. Dana perimbangan yang diberikan ke pemerintah daerah diharapkan dapat menumbuhkan perekonomian di daerah. Dan secara bertahap pemerintah daerah dapat mandiri dan menutup pengeluarannya dengan pendapatan yang berasal dari pendapatan asli daerah. Namun dalam kenyataaan hal ini belum bisa terlaksana setelah dua puluh tahun desentralisasi fiskal. Hal ini sebagaimana dinyatakan dalam situs ekonomi.bisnis.com dan www.ssas.co.id, tanggal 28 Mei 2019, bahwa "upaya pemerintah untuk mendorong desentralisasi fiskal belum menunjukan perkembangan yang signifikan. Pasalnya, setiap tahun ketergantungan daerah terhadap alokasi anggaran dari pusat masih cukup tinggi." Lebih lanjut dalam situs tersebut Wakil Menteri Keuangan Mardiasmo mengatakan perlunya kombinasi kebijakan sebagai pendorong optimalnya desentralisasi fiskal, dengan melakukan perbaikan aspek regulasi salah satunya terkait Undang-Undang Perimbangan Keuangan Antara Pusat dan Daerah.

Data empat tahun terakhir jumlah dana perimbangan yang diberikan oleh pemerintah pusat ke pemerintah daerah adalah sebagai berikut seperti terlihat dalam tabel 1. 
Tabel 1. Dana Perimbangan dalam empat tahun terakhir (Dalam trilyun rupiah)

\begin{tabular}{cccc}
\hline Tahun & DAU & DAK & DBH \\
\hline 2015 & 355 & 55 & 78 \\
2016 & 385 & 154 & 88 \\
2017 & 399 & 161 & 79 \\
2018 & 402 & 168 & 93 \\
\hline
\end{tabular}

Saat ini hampir seluruh pemerintah daerah masih memperoleh DAU dari pemerintah pusat, hanya Pemerintah DKI Jakarta saja yang merupakan satusatunya pemerintah daerah yang tidak memperoleh DAU. Sementara itu pemerintah daerah lain masih memperoleh DAU yang berarti bahwa daerah lain belum bisa memenuhi kebutuhan dasarnya dari Pendapatan Asli Daerah atau masih terdapat celah fiskal. Dengan kata lain pemerintah daerah secara umum belum bisa mandiri karena Pendapatan Asli Daerah-nya masih belum bisa menutupi kebutuhan dasar.

Kondisi ini sangat tidak sesuai dengan cita-cita desentralisasi fiskal, di mana daerah diharapkan dapat mengelola keuangannya secara otonomi dan mandiri yang berarti harus bisa menutupi kebutuhan dasarnya. Perjalanan 20 tahun desentralisasi fiskal ternyata belum bisa menjadikan daerah mandiri. Pemberian dana perimbangan di awal desentralisasi fiskal yang dimaksudkan untuk perimbangan keuangan pusat dan daerah serta mendorong kemandirian ternyata belum tercapai. Hal ini mendorong penulis ingin mengetahui apakah pemberian dana perimbangan oleh pemerintah pusat kepada daerah meningkatkan kemandirian daerah yang dalam hal ini adalah meningkatkan pendapatan asli daerah.

Penelitian terkait pengaruh dana perimbangan terhadap kemandirian sebenarnya telah dilakukan oleh beberapa peneliti terlebih dahulu. Beberapa penelitian terkait antara lain penelitian Bestari (2018) yang meneliti mengenai hubungan Tingkat Kemandirian Keuangan Daerah dengan Dana Alokasi Umum, Dana Alokasi Khusus dan Dana Bagi Hasil di Kabupaten dan Kota Provinsi Sumatera Barat dan Sumatera Utara. Hasilnya menunjukkan bahwa tingkat kemandirian daerah di Sumatera Utara secara signifikan dipengaruhi oleh Dana Alokasi Umum dan Dana Alokasi Khusus, namun tidak dipengaruhi oleh Dana Bagi Hasil.

Penelitian Marizka (2013) di Sumatera Barat menghasilkan simpulan bahwa kemandirian daerah secara signifikan dipengaruhi oleh Dana Alokasi Umum dan Dana Bagi hasil, namun tidak terpengaruh secara signifikan oleh dana alokasi khusus. Jika disandingkan dengan penelitian Bestari maka hasil ini sedikit berbeda. Kedua penelitian memperoleh hasil bahwa Dana Alokasi Umum mempunyai pengaruh yang signifikan terhadap kemandirian. Berbeda dengan penelitian yang dilakukan oleh Bestari yang mengatakan bahwa kemandirian daerah dipengaruhi secara signifikan oleh Dana Alokasi Khusus, penelitian Marizka menunjukkan bahwa kemandirian daerah tidak dipengaruhi secara signifikan oleh Dana Alokasi Khusus. Demikian pula hubungan antara kemandirian daerah dengan Dana Bagi Hasil yang menunjukkan hasil berbeda. Penelitian Bestari menunjukkan bahwa kemandirian daerah tidak terpengaruhi secara signifikan oleh Dana Bagi Hasil, sedangkan penelitian Marizka menunjukkan sebaliknya.

Penelitian sejenis yang dilakukan oleh Siagian (2014) di pemerintahan kota/kabupaten di propinsi Riau menunjukkan hasil yang mirip dengan penelitian Bestari yaitu Dana Alokasi Umum secara signifikan mempunyai pengaruh terhadap kemandirian, begitu juga dengan Dana Alokasi Khusus. Sedangkan Dana Bagi Hasil berdasarkan hasil uji hipotesis tidak signifikan berpengaruh terhadap kemandirian daerah. Purmina (2015) melakukan penelitian di propinsi Jawa Timur dan memberikan hasil yang berbeda dengan penelitian yang lain yaitu Dana Alokasi Umum dan Dana Alokasi Khusus mempunyai pengaruh yang negatif terhadap kemandirian, sedangkan Dana Bagi Hasil tidak berpengaruh terhadap kemandirian.

Sari (2015) melakukan penelitian yang hampir mirip dengan variabel independen Dana Alokasi Umum, Dana Alokasi Khusus, dan Belanja Modal pada pemerintah daerah di Yogyakarta, memperoleh hasil bahwa Dana Alokasi Umum mempunyai pengaruh yang signifikan dan positif, sementara Dana Alokasi Khusus mempunyai pengaruh yang signifikan namun negatif. Sedangkan variabel belanja modal mempunyai pengaruh positif signifikan terhadap kemandirian.

Penelitian Ariani (2016) yang berjudul Pengaruh Belanja Modal Dan Dana Alokasi Umum Terhadap Tingkat Kemandirian Keuangan Daerah yang dilakukan di Jawa Tengah memperoleh hasil bahwa Belanja Modal mempunyai pengaruh yang signifikan terhadap kemandirian daerah. Sementara Dana Alokasi Umum mempunyai pengaruh yang negatif terhadap kemandirian daerah.

Darwis (2016) meneliti mengenai pengaruh belanja modal dan belanja pegawai terhadap kemandirian daerah di Sumatera Barat. Hasilnya menunjukkan bahwa belanja modal berpengaruh negatif signifikan terhadap kemandirian begitu juga dengan belanja pegawai.

Penelitian-penelitian terdahulu terkait dengan pengaruh dana perimbangan dan belanja modal terhadap kemandirian daerah ternyata memberikan hasil yang berbeda-beda. Selain itu penelitian terdahulu lebih banyak dilakukan secara regional. Dalam penelitian ini penulis melakukan penelitian yang serupa dengan menggabungkan variabel dan memperluas cakupan wilayah. Penelitian ini dilakukan untuk skala nasional.

Hasil penelitian ini diharapkan dapat memberikan gambaran yang lebih utuh atas pengaruh dana perimbangan dan belanja modal pemerintah daerah terhadap kemandirian daerah. Sehingga dapat memberikan masukan kepada pemerintah pusat terutama Direktorat Jenderal Perimbangan Keuangan dalam mengalokasikan dana perimbangan dan juga memberikan masukan yang konkrit kepada pemerintah daerah dalam mengalokasikan belanja modal guna 
meningkatkan kemandirian daerah melalui peningkatan Pendapatan Asli Daerah.

Berdasarkan pada hasil penelitian sebelumnya dan hasil pemikiran logis penulis membuat rerangka penelitian bahwa kemandirian daerah dipengaruhi oleh beberapa variabel antara lain Dana Alokasi Umum, Dana Alokasi Khusus, dan Dana Bagi Hasil yang diterima oleh Pemerintah Daerah sebagai sumber pendapatan yang akan digunakan untuk belanja pemerintah daerah yang menjadi stimulus perekonomian daerah. Selain itu Belanja Modal yang dikeluarkan oleh pemerintah daerah yang digunakan untuk memperoleh aset jangka panjang dan insfrastruktur menjadikan stimulus ekonomi daerah yang pada akhirnya akan meningkatkan pendapatan daerah pada periode berikutnya. Semakin besar Pendapatan asli Daerah yang diperoleh oleh pemerintah daerah maka kemandirian daerah tersebut semakin tinggi. Secara umum rerangka yang dibuat oleh penulis seperti pada gambar 1 .

Gambar 1. Rerangka Penelitian

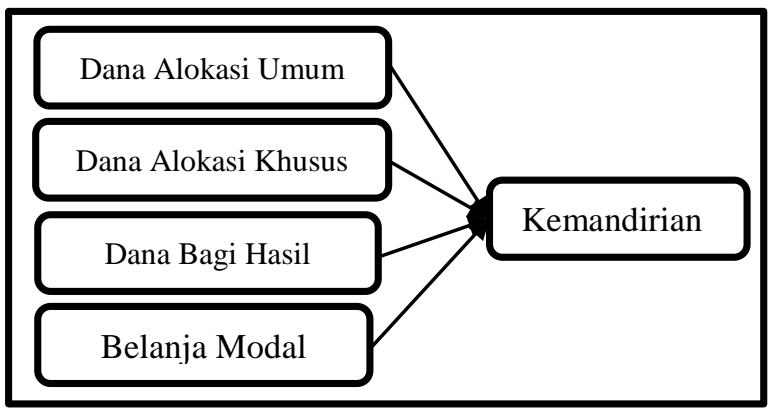

\section{KERANGKA TEORI DAN PENGEMBANGAN HIPOTESIS}

\subsection{Desentralisasi}

Pengertian Desentralisasi menurut Ghuman dan Singh (2013) merupakan transfer kekuasaan, wewenang, tanggung jawab dan sumber daya dari pemerintah pusat ke unit administrasi menengah dan lokal di bawahnya. Tujuan dari desentralisasi mengarah pada peningkatan kualitas dengan meningkatkan akuntabilitas dan transparansi melalui partisipasi masyarakat dan pemantauan pengambilan keputusan dan proses penyediaan layanan publik.

Perimbangan keuangan sebagai bentuk dari pelaksanaan desentralisasi di Indonesia, terdiri dari pembagian dana berupa Dana Alokasi Umum (DAU), Dana Alokasi Khusus (DAK) dan Dana Bagi Hasil (DBH) dari pemerintah pusat ke pemerintah daerah (UU Nomor 33 Tahun 2004). Tujuan dari ketiga dana perimbangan yang berasal dari dana APBN adalah untuk meminimalisir ketimpangan dari kemampuan antardaerah dalam memenuhi kebutuhan keuangannya (horizontal imbalance) yang hanya diperoleh dari sumber Pendapatan Asli Daerah (PAD) saja. Pengalokasin dana perimbangan berupa Dana Alokasi Umum dan Dana Alokasi Khusus menekankan pada aspek pemerataan dan keadilan yang selaras dengan penyelenggaraan urusan pemerintah (UU No. 32 Tahun 2004).

\subsection{Kemandirian daerah}

Sumber pendapatan pemerintah daerah secara umum diklasifikasikan menjadi tiga kelompok besar yaitu Pendapatan Asli Daerah, Dana Perimbangan/Transfer, dan Lain-lain Pendapatan Daerah yang Sah. Adapun dari ketiga jenis pendapatan tersebut pendapatan yang berasal dari daerah itu sendiri adalah Pendapatan Asli Daerah, sedangkan kedua jenis pendapatan daerah yang lain adalah pendapatan yang berasal dari pemerintahan yang lebih tinggi atau entitas lain. Sehingga kemandirian fiskal/keuangan suatu daerah sangat erat dengan Pendapatan Asli Daerah.

Daerah yang mandiri berarti daerah yang mampu membiayai kegiatan pemerintahannya dengan menggunakan Pendapatan Asli Daerahnya. Semakin besar Pendapatan Asli Daerah yang dapat diperoleh maka akan semakin mandiri. Rinaldi (2013) menyatakan bahwa yang selalu dipandang sebagai salah satu kriteria atau indikator dalam mengukur ketergantungan suatu daerah kepada pusat adalah Pendapatan Asli Daerah. Kemampuan daerah dalam memperoleh Pendapatan Asli Daerah-nya merupakan salah satu ukuran kemandirian suatu daerah.

\subsection{Dana Alokasi Umum}

Dalam Undang-Undang Nomor 32 Tahun 2004, penyelenggaraan urusan pemerintah dalam hal pengalokasian dana perimbangan berupa Dana Alokasi Umum menekankan pada aspek pemerataan dan keadilan. Pemerintah daerah yang menerima Dana Alokasi Umum akan memperlakukan dana tersebut sebagai pendapatan daerah yang berasal dari transfer pemerintah pusat. Pendapatan ini selanjutnya akan digunakan untuk membiayai belanja pemerintah daerah. Belanja pemerintah daerah diharapkan akan menciptakan pertumbuhan ekonomi pemerintah daerah yang pada akhirnya akan memberikan kontribusi pada Pendapatan Asli Daerah sehingga kemandirian daerah diharapkan semakin meningkat.

Frelistiyani, W dan Rohman (2011), melakukan penelitian pengaruh Dana Alokasi Umum Terhadap Pendapatan Asli Daerah di Pemerintah Kabupaten/Kota Se-Jawa untuk periode 2006-2008, menyatakan bahwa Dana Alokasi Umum mempunyai pengaruh yang signifikan terhadap Pendapatan Asli Daerah. Bestari (2018) menyatakan terdapat pengaruh yang positif signifikan antara Dana Alokasi Umum dengan Kemandirian daerah. Penelitian yang sejenis dan menghasilkan kesimpulan yang sama adalah penelitian Marizka (2013), Siagian (2014), dan Sari (2015). Hasil dari penelitian tersebut menyatakan bahwa Dana Alokasi Umum mempunyai pengaruh positif signifikan terhadap kemandirian daerah.

Berdasarkan pada pemikiran dan hasil penelitianpenelitian terdahulu penulis merumuskan hipotesa sebagai berikut:

$\mathrm{H} 1=$ Dana Alokasi Umum mempunyai pengaruh yang positif signifikan terhadap kemandirian pemerintah daerah. 


\subsection{Dana Alokasi Khusus}

Sama seperti Dana Alokasi Umum, pengalokasian dana perimbangan berupa Dana Alokasi Khusus juga menekankan pada aspek pemerataan dan keadilan. Pemerintah daerah menggunakan DAK untuk belanja daerah. Yang berbeda adalah mengenai peruntukkannya, di mana DAK harus digunakan untuk belanja daerah yang telah ditetapkan oleh pemerintah pusat dan tidak bisa digunakan untuk lainnya. Namun demikian dampak belanja tersebut semestinya akan sama dengan Dana Alokasi Umum yaitu akan meningkatkan perekonomian di daerah tersebut yang pada akhirnya akan menyumbang Pendapatan Asli Daerah.

Lede (2012) melakukan penelitian terkait pengaruh Dana Alokasi Khusus terhadap peningkatan Pendapatan Asli Daerah yang hasilnya menunjukkan adanya pengaruh Dana Alokasi Khusus terhadap Pendapatan Asli Daerah. Sementara penelitian Siagian (2014) menyatakan adanya pengaruh Dana Alokasi Khusus terhadap kemandirian daerah. Lebih lanjut penelitian Bestari (2018) juga menyatakan adanya pengaruh Dana Alokasi Khusus terhadap kemandirian daerah.

Berdasarkan pada pemikiran dan hasil penelitianpenelitian terdahulu penulis merumuskan hipotesa sebagai berikut:

$\mathrm{H} 2=$ Dana Alokasi Khusus mempunyai pengaruh yang positif signifikan terhadap kemandirian pemerintah daerah.

\subsection{Dana Bagi Hasil}

Tujuan utama pemberian DBH adalah untuk melakukan perbaikan dan menjaga keseimbangan vertikal antara pemerintah pusat dan pemerintah daerah dengan memperhatikan potensi pendapatan daerah penghasil. Dana Bagi Hasil yang diterima pemerintah daerah terdiri dari Dana Bagi Hasil Pajak dan Dana Bagi Hasil Sumber Daya Alam. Dana Bagi Hasil Pajak terdiri dari Pajak Penghasilan, Pajak Bumi dan Bangunan, dan Cukai Hasil Tembakau. Sedangkan Dana Bagi Hasil Sumber Daya Alam terdiri dari Kehutanan, Minyak Bumi dan Gas Bumi, Mineral dan Batu Bara, Pengusahaan Panas Bumi, dan Perikanan.

Sama seperti dana perimbangan yang lain, Dana Bagi Hasil juga menjadi pendapatan pemerintah daerah yang dianggarkan dan dicatat dalam Anggaran Pendapatan Belanja Daerah, dana ini juga merupakan sumber pendapatan yang diguankan untuk membiayai pengeluaran/belanja daerah. Penggunaan Dana Bagi Hasil menjadi kewenangan sepenuhnya oleh pemerintah daerah, pemerintah pusat tidak membatasi penggunaannya. Sebagai pengeluaran pemerintah daerah, penggunaan dana bagi hasil juga diharapkan dapat meningkatkan kemampuan daerah dalam menghasilkan pendapatan asli daerah di kemudian hari. Anitasari dan Soleh (2015) dalam penelitiannnya menyatakan bahwa pengeluaran pemerintah secara signifikan dan positif berpengaruh terhadap pertumbuhan ekonomi. Dengan demikian seyogyanya Dana Bagi Hasil juga akan memberikan dampak yang positif terhadap pertumbuhan ekonomi sehingga
Pendapatan Asli Daerah yang merupakan indikator kemandirian daerah pada akhirnya akan meningkat.

Marizka (2013) menyatakan bahwa Dana Bagi Hasil mempunyai pengaruh positif signifikan terhadap kemandirian. Yani (2002) menyatakan bahwa semakin besarnya persentase dana yang dibagi kepada daerah, semakin besar pula kontribusi yang diberikan Dana Bagi Hasil terhadap pendapatan daerah, dan sebaliknya. Noviyanto tahun 2005 melakukan penelitian di Yogyakarta dan hasilnya menyatakan Dana Bagi Hasil berpengaruh positif terhadap tingkat kemandirian keuangan daerah.

Berdasarkan pada pemikiran dan hasil penelitianpenelitian terdahulu penulis merumuskan hipotesa ketiga sebagai berikut:

H3 = Dana Bagi Hasil mempunyai pengaruh yang positif signifikan terhadap kemandirian daerah.

\subsection{Belanja Modal}

Belanja modal diartikan sebagai pengeluaran pemerintah yang secara ekonomi akan meningkatkan pertumbuhan ekonomi. Belanja modal yang di dalamnya adalah termasuk belanja infrastruktur diharapkan mampu menciptakan efek multiplier terhadap pertumbuhan ekonomi yang pada akhirnya pendapatan asli daerah dapat meningkat baik berupa pajak maupun retribusi daerah.

Penelitian Sari tahun 2015 di Yogyakarta menyatakan bahwa Belanja Modal berpengaruh secara signifikan dan positif terhadap kemandirian daerah. Penelitian sejenis yang dilakukan oleh Ariani pada tahun 2016 di Jawa Tengah juga menghasilkan kesimpulan yang sama yaitu Belanja Modal berpengaruh secara signifikan dan positif terhadap kemandirian daerah.

Berdasarkan pada pemikiran dan hasil penelitianpenelitian terdahulu penulis merumuskan hipotesa keempat dan kelima sebagai berikut:

H4 = Belanja Modal mempunyai pengaruh yang positif signifikan terhadap kemandirian daerah.

H5 = Dana Alokasi Umum, Dana Alokasi Khusus, Dana Bagi Hasil, dan Belanja Modal secara bersamasama mempunyai pengaruh yang positif signifikan terhadap kemandirian daerah.

Persamaan regresi yang dibuat untuk mengambarkan kelima hipotesis tersebut adalah sebagai berikut:

$$
\mathrm{Y}=\mathrm{a}+\mathrm{b} 1 \cdot \mathrm{x} 1+\mathrm{b} 2 \cdot \mathrm{x} 2+\mathrm{b} 3 \cdot \mathrm{x} 3+\mathrm{b} 4 \cdot \mathrm{x} 4+\varepsilon
$$

Dimana:
$\mathrm{Y}=$ Kemandirian Daerah (Pendapatan asli Daerah Tahun berikutnya)
x1 = Dana Alokasi Umum
x2 = Dana Alokasi Khusus
x3 = Dana Bagi Hasil
x4 = Belanja Modal 


\section{METODE PENELITIAN}

\subsection{Jenis Penelitian}

Penelitian ini merupakan penelitian dengan pendekatan kuantitatif, yaitu penelitian dengan menggunakan alat analisis dengan statistik. Dalam penelitian ini Penulis menggunakan data sekunder yang diperoleh dari Direktorat Jenderal Keuangan. Data penelitian merupakan data panel yang merupakan perpaduan data time series dan juga data cross sectional. Jumlah data yang digunakan dalam penelitian adalah data sampling dari 150 kabupaten/kota dengan jangka waktu 4 tahun dari tahun 2015 sampai dengan 2018. Sehingga total data sebanyak 600 data. Sampel diperoleh secara purposive sampling dengan mengutamakan kelengkapan data yang disediakan pada Portal Direktorat Jenderal Perimbangan Keuangan, Kementerian Keuangan.

\subsection{Definisi Operasional Variabel}

Variable dalam penelitian ini didefinisikan sebagai berikut:

a. Kemandirian daerah

Kamus Besar Bahasa Indonesia daring mengartikan mandiri sebagai keadaan dapat berdiri sendiri, tidak bergantung pada orang lain. Jadi kemandirian secara umum mempunyai arti keadaan di mana sesuatu dapat berdiri tanpa bergantung pada orang lain. Kemandirian daerah dapat diterjemahkan sebagai kondisi di mana pemerintah daerah tidak tergantung pada entitas lain baik pemerintah pusat maupun pemerintah yang lebih tinggi. Halim (2004) menyatakan bahwa Kemandirian fiskal menggambarkan kapasitas pemerintah daerah dalam memberikan pembiayaan atas kegiatan pemerintahan, pembangunan, dan pelayanan secara mandiri kepada masyarakat. Dengan demikian pemerintah daerah yang mandiri berarti pemerintah daerah yang mampu membiayai kegiatannya, yaitu pelayanan publik, secara sendiri dan tidak tergantung dari pemerintah pusat. Pada penelitian ini penulis menggunakan Pendapatan Asli Daerah sebagai ukuran kemandirian daerah, semakin besarnya Pendapatan Asli daerah diperoleh, ketergantungan Pemerintah Daerah atas Pemerintah Pusat akan semakin kecil. Pendapatan Asli Daerah yang digunakan adalah pendapatan asli Daerah yang diperoleh tahun berikutnya.

\section{b. Dana Alokasi Umum}

Didefinisikan sebagai transfer yang diberikan oleh pemerintah pusat dari APBN kepada pemerintah daerah, dimaksudkan untuk pemerataan kemampuan keuangan antara pemerintah pusat dengan daerah dan sesama pemerintah daerah. DAU diberikan oleh pemerintah pusat dalam bentuk gelondongan (block grant) yang peruntukkannya tidak dibatasi oleh pemerintah pusat. Secara umum pemberian Dana Alokasi Umum dimaksudkan untuk menutupi terjadinya celah fiskal yang dimiliki oleh daerah. Adapun yang dimaksud celah fiskal adalah selisih antara fiskal yang dibutuhkan dengan kapasitas fiskal yang tersedia pada daerah.

\section{c. Dana Alokasi Khusus}

Didefinisikan sebagai transfer dari pemerintah pusat yang berasal dari APBN yang diberikan kepada pemerintah daerah untuk tujuan/penggunaan yang telah ditentukan oleh pemerintah pusat. Kegiatan khusus yang didanai dengan DAK harus merupakan urusan daerah, sesuai prioritas nasional yang dimuat dalam Rencana Kerja Pemerintha. DAK terdiri dari DAK Non-Fisik dan DAK Fisik yang secara umum di bagi dalam beberapa bidang.

\section{d. Dana Bagi Hasil}

Didefinisikan sebagai dana yang diterima oleh pemerintah daerah yang bersumber dari pendapatan APBN sebagai bagi hasil atas pendapatan pajak dan sumber daya alam yang diterima oleh pemerintah pusat. Alokasi kepada daerah dilakukan dalam rangka pelaksanaan desentralisasi yang perhitungannya berdasarkan angka persentase tertentu untuk mendanai kebutuhan daerah yang bersangkutan. Pembagian alokasi DBH kepada daerah didasarkan pada prinsip by origin, sedangkan penyaluran DBH dilakukan atas dasar prinsip realisasi pendapatan (Based on Actual Revenue), yaitu berdasarkan pada realisasi penerimaan pendapatan pada tahun berjalan.

\section{e. Belanja Modal}

Didefinisikan sebagai pengeluaran pemerintah dalam rangka pembentukan modal, sifatnya menambah aset tetap atau aset lainnya, dan memberikan manfaat lebih dari satu tahun atau periode akuntansi. Pengeluaran yang dilakukan untuk pembiayaan pemeliharaan yang sifatnya menambah masa manfaat dan menyebabkan kapasitas serta kualitas aset meningkat, termasuk dalam kategori belanja modal. Belanja modal terdiri dari tanah, peralatan dan mesin, gedung dan bangunan, jalan, irigasi dan jaringan, dan belanja modal fisik lainnya. Secara umum belanja modal merupakan belanja aset jangka panjang yang diharapkan memberikan manfaat lebih dari satu tahun termasuk belanja infrastruktur.

\subsection{Metode Analisis Data}

Pengolahan data dilakukan dengan menggunakan regresi berganda melalui aplikasi STATA. Untuk memilih model yang akan digunakan terlebih dahulu dilakukan uji model. Uji model yang pertama adalah uji Chow untuk membandingan antar model Fixed Effect dengan Pooled Least Square, hasilnya, karena Prob $>\mathrm{F}<0.05$, maka Fixed Effect lebih baik dari Pooled Least Square. Uji berikutnya adalah uji Lagrange Multiplier untuk membandingkan model Random Effect dengan Pooled Least Square, hasilnya, Karena Prob>Chibar2 < 0.05, maka Random Effect lebih baik dari Pooled Least Square. Dan terakhir menguji model dengan uji Hausman untuk membandingkan antara Fixed Effect dengan Random Effect. Hasil uji Hausman menunjukkan bahwa prob>chi2 < 0.05, maka Fixed Effect lebih bagus. Berdasarkan hasil uji model maka model regresi yang paling fit adalah Fixed-Effect Model Regression. FixedEffect Model adalah model yang dapat mengakomodasi perbedaan karakteristik antarindividu yang menjadi 
masalah pada model koefisien konstan (Pooled Regression) melalui intersepnya.

\section{HASIL PENELITIAN}

\subsection{Statistik Deskriptif}

Data sekunder dalam penelitian ini diambil dari portal Direktorat Jenderal Perimbangan Keuangan, Kementerian Keuangan. Jumlah data yang digunakan sebanyak 150 Kabupaten/Kota untuk periode 4 tahun dengan sebaran seperti dalam tabel 2 .

Tabel 2. Sebaran data penelitian per propinsi

\begin{tabular}{|c|c|c|c|c|c|}
\hline No & Propinsi & $\mathrm{Jml}$ & No & Propinsi & $\mathrm{Jml}$ \\
\hline 1 & Aceh & 5 & 17 & Kep. Riau & 3 \\
\hline 2 & Bali & 3 & 18 & Lampung & 2 \\
\hline 3 & Banten & 2 & 19 & Maluku & 1 \\
\hline 4 & Bengkulu & 3 & 20 & Maluku Utara & 3 \\
\hline 5 & Gorontalo & 2 & 21 & NTB & 5 \\
\hline 6 & Jambi & 6 & 22 & NTT & 2 \\
\hline 7 & Jawa Barat & 7 & 23 & Papua & 8 \\
\hline 8 & Jawa Tegah & 1 & 24 & Papua Barat & 4 \\
\hline 9 & Jawa Tengah & 10 & 25 & Riau & 3 \\
\hline 10 & Jawa Timur & 11 & 26 & Sulawesi Selatan & 13 \\
\hline 11 & JawaTimur & 1 & 27 & Sulawesi Tengah & 6 \\
\hline 12 & $\begin{array}{l}\text { Kalimantan } \\
\text { Barat }\end{array}$ & 4 & 28 & Sulawesi Tenggara & 5 \\
\hline 13 & $\begin{array}{l}\text { Kalimantan } \\
\text { Selatan }\end{array}$ & 3 & 29 & Sulawesi Utara & 5 \\
\hline 14 & $\begin{array}{l}\text { Kalimantan } \\
\text { Tengah }\end{array}$ & 4 & 30 & Sumatera Barat & 4 \\
\hline 15 & $\begin{array}{l}\text { Kalimantan } \\
\text { Timur }\end{array}$ & 2 & 31 & Sumatera Selatan & 6 \\
\hline 16 & $\begin{array}{l}\text { Kep. Bangka } \\
\text { Belitung }\end{array}$ & 2 & 32 & Sumatera Utara & 14 \\
\hline
\end{tabular}

Adapun statistik deskripsi untuk masing-masing variabel seperti ditunjukkan pada tabel 3 berikut:

Tabel 3. Deskripsi Statistik Variabel Penelitian

\begin{tabular}{lrrr}
\hline Variabel & Rata-rata & \multicolumn{1}{c}{$\begin{array}{c}\text { Nilai } \\
\text { Minimal }\end{array}$} & \multicolumn{1}{c}{$\begin{array}{c}\text { Nilai } \\
\text { Maksimal }\end{array}$} \\
\hline DAU & 683.101 .039 .960 & 290.035 .577 .000 & 2.096 .677 .101 .000 \\
DAK & 149.734 .964 .766 & 1.394 .025 .000 & 645.086 .445 .696 \\
DBH & 99.211 .191 .002 & 10.145 .059 .970 & 2.052 .760 .997 .515 \\
Bel. Modal & 313.102 .388 .798 & 51.980 .727 .019 & 1.459 .440 .715 .122 \\
PAD & 218.271 .921 .806 & 3.539 .430 .038 & 2.578 .457 .420 .885 \\
\hline
\end{tabular}

\subsection{Uji Hipotesis}

Uji asumsi klasik dilakukan terlebih dahulu sebelum dilakukan uji hipotesis. Karena data yang digunakan adalah data panel maka penulis melakukan uji asumsi klasik untuk multikolinearitas dan heteroskedastisitas. Hasil uji multikolinearitas menunjukkan nilai VIF semuanya masih di bawah 10 $(\mathrm{VIF}<10)$ sehingga dapat disimpulkan tidak terdapat permasalahan multikoleniaritas. Hasil uji multikolinearitas dengan stata dapat dilihat pada gambar 2 berikut.
Gambar 2. Hasil Uji Multikolinearitas

\begin{tabular}{|r|rr|}
\hline Vif, uncentered & \\
Variable & VIF & $1 /$ VIF \\
\hline BModal & 8.20 & 0.121941 \\
DAU & 8.06 & 0.124044 \\
DAK & 3.97 & 0.251750 \\
DBH & 2.15 & 0.464160 \\
\hline Mean VIF & 5.60 & \\
\hline
\end{tabular}

Sumber: Olahan Stata

Uji heteroskedastisitas pada Fixed Effect Model dilakukan dengan menggunakan xttest3 dan ternyata ditemukan permasalahan heteroskedastisitas. Untuk menanggulangi masalah tersebut maka digunakan robust standard error. Hasil uji hipotesis secara lengkap dapat dilihat pada Gambar 3 berikut.

Gambar 3. Hasil Uji Hipotesis

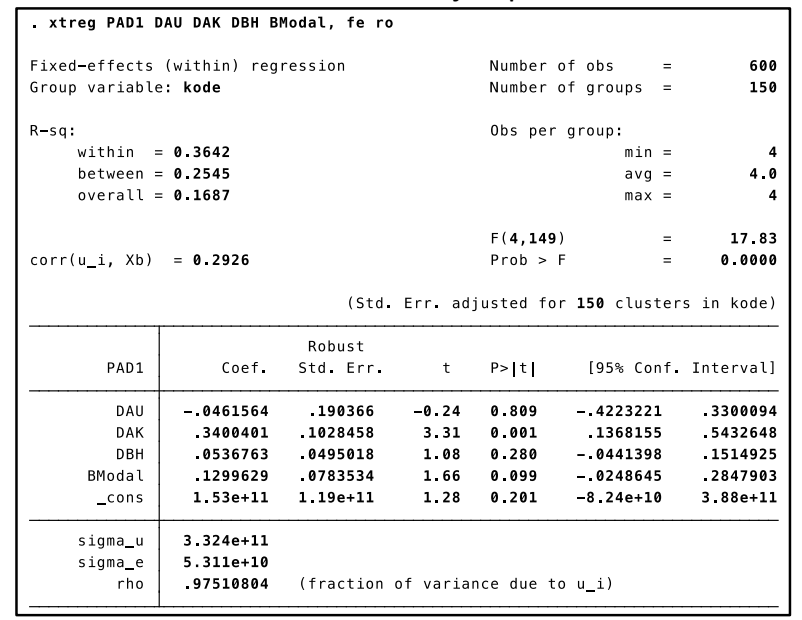

Sumber: Hasil Olahan Stata

Berdasarkan hasil uji regresi dengan fixed effect diperoleh bahwa R-square overall adalah sebesar 0,1687 atau $16,87 \%$ yang berarti model yang dibuat mampu menjelaskan bahwa sebesar $16,68 \%$ variabel dependent dipengaruhi variabel independen yang dihipotesiskan dalam penelitian sedangkan sebesar 83,32\% dipengaruhi variabel lain. Artinya bahwa variabel Dana Alokasi Umum, Dana Alokasi Khusus, Dana Bagi Hasil, dan Belanja Modal hanya mempengaruhi Variabel Kemandirian daerah sebesar $16,68 \%$. Jadi masih sangat banyak variabel lain yang dapat mempengaruhi Kemandirian daerah yang belum/tidak diteliti dalam penelitian ini.

Nilai signifikansi $(P>|t|)$ untuk variabel DAU adalah sebesar 0,809 ini berarti lebih besar dari 0,05 sehingga dapat disimpulkan bahwa Dana Alokasi Umum tidak berpengaruh signifikan terhadap Kemandirian Daerah. Hal ini tidak sejalan dengan hipotesis pertama yang dibuat oleh penulis atau dengan kata lain hipotesis pertama tidak terbukti. Hal ini terjadi karena sebagian besar pemerintah daerah menggunakan Dana Alokasi Umum untuk belanja Pegawai. Dana Alokasi Umum digunakan oleh pemerintah daerah untuk menutup celah fiskal yaitu selisih antara kapasitas fiskal yang tersedia dengan kebutuhan dasar yang salah satunya adalah belanja pegawai. Belanja pegawai adalah belanja pemerintah yang dibayarkan ke pegawai sebagai kompensasi atas kinerja yang dilakukan pegawai 
sehingga tidak menghasilkan aset jangka panjang dan investasi bagi pemerintah daerah yang diharapkan mampu memberi manfaat yang multi periode dan mampu mendongkrak perekonomian dengan lebih cepat.

Uji hipotesis kedua dapat dilihat dari nilai $(P>|t|)$ Dana Alokasi Khusus yang bernilai 0,001, artinya lebih kecil dari 0,05. Dari uji hipotesis disimpulkan bahwa Dana Alokasi Khusus berpengaruh secara signifikan terhadap Kemandirian Daerah. Nilai Koefisien untuk DAK adalah sebesar $+0,3400$ ini berarti Dana Alokasi Khusus berpengaruh positif, artinya semakin besar Dana Alokasi Khusus yang diterima oleh Pemerintah Daerah akan menambah kemandirian daerah pada periode berikutnya dengan meningkatnya Pendapatan asli Daerah. Sehingga dapat disimpulkan bahwa hipotesis kedua terbukti yaitu Dana Alokasi Khusus berpengaruh positif signifikan terhadap kemandirian daerah.

Variabel Dana Bagi Hasil mempunyai nilai $(P>|t|)$ sebesar 0,280, artinya lebih besar dari 0,05. Disimpulkan bahwa Dana Bagi Hasil tidak berpengaruh secara signifikan terhadap kemandirian daerah. Dari hasil ini juga menunjukkan bahwa hipotesis ketiga penelitian ini tidak terbukti. Hal ini dapat dijelaskan karena terdapat kesenjangan yang cukup besar atas penerimaan jumlah Dana Bagi Hasil antara pemerintah daerah satu dengan daerah yang lainnya. Nilai minimal Dana Bagi Hasil adalah Rp10.145.059.970 sedangkan nilai maksimal adalah Rp2.052.760.997.515. Selain itu penggunaan Dana Bagi Hasil menjadi kewenangan pemerintah daerah masing-masing sehingga penggunaannya sangat bervariatif. Untuk Daerah yang memperoleh Dana bagi Hasil relatif besar, dapat mengalolasikan dana tersebut untuk belanja infrastruktur yang dapat mendongkrak perekonomian, selanjutnya dapat meningkatkan potensi pendapatan daerahnya. Namun hal ini berbeda dengan daerah yang menerima Dana Bagi Hasil yang kecil, kecenderungannya menggunakan dana tersebut untuk belanja non infrastuktur.

Variabel terakhir adalah Belanja Modal. Berdasarkan hasil uji regresi diperoleh nilai $(P>|t|)$ untuk Belanja Modal sebesar 0,09. Koefisien untuk Belanja Modal adalah $+0,12996$, ini berarti pengaruh Belanja Modal terhadap kemandirian daerah adalah positif. Namun jika kita melihat pada nilai signifikansinya yang 0,09, artinya lebih besar dari 0,05, sehingga dapat dikatakan bahwa Belanja Modal tidak signifikan mempengaruhi Kemandirian daerah meskipun arahnya positif. Simpulan yang dapat diambil adalah bahwa Belanja Modal tidak berpengaruh signifikan terhadap Kemandirian daerah. Hasil ini berbeda dengan hipotesis keempat yang dibuat oleh penulis, dengan demikian hipotesis keempat ditolak. Belanja Modal tidak signifikan mempengaruhi kemandirian karena sebagian besar Belanja Modal pemerintah daerah adalah bersifat penyediaan layanan pemerintah seperti pembangunan gedung kantor, pemenuhan peralatan perkantoran, dan pemeliharaan kantor, dibanding dengan pembangunan infrastuktur yang mendukung perekonomian seperti jalan dan jembatan.

Meskipun secara individu tidak semua variabel terbukti secara signifikan mempengaruhi kemandirian namun secara simultan variabel Dana Alokasi Umum, Dana Alokasi Khusus, Dana Bagi Hasil, dan Belanja Modal ternyata signifikan mempengaruhi kemandirian daerah. Hal ini ditunjukkan dengan nilai Prob $>F$ yang sebesar 0,0000 yang berarti lebih kecil dari 0,005. Dengan demikian hipotesis kelima terbukti.

\section{KESIMPULAN DAN SARAN}

\subsection{Kesimpulan}

Berdasarkan pada pengujian dan analisis, kesimpulan yang dapat ditarik adalah sebagai berikut:

1. Dana Alokasi Umum tidak signifikan mempengaruhi kemandirian daerah. Hal ini karena Dana Alokasi Umum yang diterima oleh pemerintah daerah adalah untuk menutup celah fiskal dan memenuhi kebutuhan dasar terutama untuk belanja pegawai.

2. Dana Alokasi Khusus secara signifikan mempengaruhi kemandirian daerah karena sebagian Dana Alokasi Khusus adalah untuk pembangunan infrastuktur yang dapat mendongkrak perekonomian.

3. Dana Bagi Hasil tidak signifikan mempengaruhi kemandirian daerah. Hal ini dapat dijelaskan karena variabilitas jumlah Dana Bagi Hasil antara daerah satu dengan yang lainnya sangat tinggi.

4. Belanja Modal tidak signifikan mempengaruhi kemandirian daerah. Hal ini karena belanja modal yang dilakukan pemerintah daerah lebih banyak digunakan untuk belanja pelayanan dasar seperti membangun gedung kantor dan pembelian peralatan perkantoran dibandingkan dengan membangun infrastruktur seperti jalan dan jembatan.

5. Secara simultan Dana Alokasi Umum, Dana Alokasi Khusus, Dana Bagi Hasil, dan Belanja Modal mempengaruhi kemandirian daerah.

\subsection{Saran}

1. Pemerintah daerah seyogyanya mendorong penggunaan Dana Alokasi Umum dan Dana Bagi Hasil untuk kegiatan yang lebih produktif.

2. Pemerintah pusat dapat memberikan lebih banyak Dana Alokasi Khusus yang bersifat fisik dan infrastruktur.

3. Pemerintah Daerah seyogyanya mengarahkan Belanja Modal untuk pemenuhan infrastuktur yang dapat mendorong peningkatan ekonomi sehingga dapat meningkatkan potensi pendapatan asli daerah.

\section{IMPLIKASI DAN KETERBATASAN}

Penelitian ini dilakukan dalam skala nasional meskipun tidak semua pemerintah daerah dijadikan objek penelitian, namun penggunaan sampel yang tersebar dari Aceh sampai Papua dianggap dapat mewakili kondisi nasional sehingga diharapkan pemerintah dapat menggunakan hasil penelitian ini untuk mengambil kebijakan. Bagi pemerintah pusat diharapkan dalam memberikan dana perimbangan ke pemerintah daerah lebih diarahkan untuk dana perimbangan yang dapat digunakan untuk pembangunan infrastruktur. Adapun bagi pemerintah 
daerah seyogyanya dapat mengoptimalkan dana perimbangan untuk belanja modal yang lebih produktif.

Keterbatasan penelitian ini antara lain pertama, penelitian dilakukan secara nasional dan tidak mengcluster karakteristik pemerintah daerah seperti size/ukuran, lokasi, wilayah, budaya, dan jenis wilayah pemerintah daerah. Untuk penelitian lebih lanjut seyogyanya dapat dilakukan pengelompokkan. Kedua, perlu pengembangan ukuran kemandirian tidak hanya menggunakan pendapatan asli daerah tapi bisa menggunakan ukuran-ukuran yang lain. Ketiga, agar dapat menambahkan variabel lain baik variabel kontrol maupun variabel independen lainnya.

\section{DAFTAR PUSTAKA}

Anitasari, M., \& Soleh, A. (2015). Pengaruh Pengeluaran Pemerintah Terhadap Pertumbuhan Ekonomi di Provinsi Bengkulu. Ekombis Review, 3(2), 43094.

Apriana, D., \& Suryanto, R. (2016). Analisis Hubungan Antara Belanja Modal, Pendapatan Asli Daerah, Kemandirian Daerah dan Pertumbuhan Ekonomi Daerah. Journal of Accounting and Investment, 11(1), 68-79.

Ariani, K. R., \& Putri, G. A. (2016). Pengaruh Belanja Modal dan Dana Alokasi Umum Terhadap Tingkat Kemandirian Keuangan Daerah.

Bestari, I. (2018). Pengaruh Dana Alokasi Umum, Dana Alokasi Khusus dan Dana Bagi Hasil terhadap Tingkat Kemandirian Keuangan Daerah Kabupaten dan Kota di Provinsi Sumatera Barat dan Sumatera Utara.

Darwis, E. T. R. (2015). Pengaruh Belanja Modal Dan Belanja Pegawai Terhadap Tingkat Kemandirian Keuangan Daerah Pada Kabupaten/Kota Provinsi Sumatera Barat (Studi Empiris Pada Kabupaten dan Kota Provinsi Sumatera Barat). Jurnal Akuntansi, 3(1).

Ghuman, B. S., \& Singh, R. (2013). Decentralization and delivery of public services in Asia. Policy and Society, 32(1), 7-21.

Halim, Abdul. (2004) Akuntansi Keuangan Daerah Edisi Revisi. Jakarta, Salemba Empat.

Lede, J. W. (2012). Pengaruh Dana Alokasi Umum, Dana Alokasi Khusus Dan Dana Bagi Hasil Terhadap Peningkatan Pendapatan Asli Daerah Melalui Belanja Modal Sebagai Variabel Intervening. Jurnal Ilmu dan Riset Akutansi, 1, 12.

Marizka, R. (2013). Pengaruh Pendapatan Asli Daerah, Dana Bagi Hasil, Dana Alokasi Umum Dan Dana Alokasi Khusus Terhadap Tingkat Kemandirian Keuangan Daerah Pada Kabupaten Dan Kota Di Sumatera Barat (Tahun 2006-2011). Jurnal Akuntansi, 1(3).
Noviyanto, Haris. (2005). Analisis Perimbangan Keuangan Pusat-Daerah dan Pinjaman Daerah di Kabupaten dan Kota Daerah Istimewa Yogyakarta Tahun 1994/1995-2003. Skripsi. Universitas Islam Indonesia.

Oates, W. E. (1999). An essay on fiscal federalism. Journal of economic literature, 37(3), 1120-1149.

Purnima, D., Saleh, C., \& Noor, I. (2015). Pengaruh Dana Bagi Hasil, Dana Alokasi Umum, Dan Dana Alokasi Khusus Terhadap Kemandirian Fiskal Dengan Desentralisasi Fiskal Sebagai Variabel Moderating Di Kabupaten Dan Kota Provinsi Jawa Timur. Jurnal Administrasi Publik (JAP), 3, 969975.

Rinaldi, U. (2012). Kemandirian Keuangan dalam Pelaksanaan Otonomi Daerah. STIE Indonesia. Jurnal Akuntansi, Vol. 8, No.2.

Sari, P. I. (2015). Pengaruh Dana Alokasi Umum, Dana Alokasi Khusus dan Belanja Modal Terhadap Tingkat Kemandirian Keuangan Daerah (Studi Kasus pada Kabupaten/Kota di DIY periode 20072014).

Siagian, S. N. (2014). Pengaruh Rasio Efektifitas Pendapatan Asli Daerah, Dana Alokasi Umum, Dana Alokasi Khusus Dan Dana Bagi Hasil Terhadap Tingkat Kemandirian Keuangan Daerah Pada Pemerintahan Kabupaten/Kota Di Provinsi Riau.

Sidik, M. (2002). Dana alokasi umum: konsep, hambatan, dan prospek di era otonomi daerah. Penerbit Buku Kompas.

Yani, Ahmad. (2002) Hubungan Keuangan antara Pemerintah Pusat dan Daerah di Indonesia. Jakarta, PT. Raja Grafindo Persada.

Undang-Undang Nomor 33 Tahun 2004 Tentang Perimbangan Keuangan Antara Pemerintah Pusat Dan Pemerintah Daerah. 2004. Jakarta.

Undang-Undang Nomor 32 Tahun 2004 Tentang Pemerintah Daerah. 2004. Jakarta.

https://ekonomi.bisnis.com/read/20190528/9/928193 desentralisasi-fiskal-belum-optimalketergantungan-daerah-ke-pusat-masih-tinggi

https://www.ssas.co.id/desentralisasi-fiskal-belumoptimal-ketergantungan-daerah-ke-pusatmasih-tinggi/ 